\title{
Lektyki i kolebki, karety i zwykłe wozy Pojazdy dla pań i panów, wielkich tego świata oraz maluczkich w Polsce średniowiecznej i wczesnonowożytnej
}

Litters and Cradles, Carriages and Ordinary Carts Vehicles for Ladies and Gentlemen, for the Great of this Word and for the Little Ones in Medieval and Early Modern Poland

\begin{abstract}
Abstrakt: Zgodnie z tytułem niniejszego artykułu jego przedmiotem są bardzo kosztowne pojazdy dla pań i panów, wielkich tego świata oraz mniej kosztowne dla kupców i wieśniaków w Polsce do Xvi w. Były to lektyki, kolebki i karety, ale na drogach dominowały zwykłe wozy kupców i wieśniaków. Najtańsze kosztowały 32 grosze, czyli 2/3 grzywny, ale najczęściej 2-3 grzywny. Królewska asseda dicta colebca w 1394 r. kosztowała aż 8 grzywien. Cennik wojewody krakowskiego Piotra Kmity z 1538 r. zawiera
\end{abstract}

4 rodzaje najbardziej popularnych wozów: rydwan z dwukonnym zaprzęgiem za 2 floreny, drugi średni za 3,5 florena i trzeci wielki rydwan za 5 florenów. Podobne ceny podają cenniki z I56I i i565 r. Nadwozia pojazdów były konstruowane z desek lub wikliny, a koła kosztowały od 6 do 24 groszy. Pojazdy lub ich części były często nakrywane płóciennymi lub sukiennymi plandekami, jak poklat, tectura, patuba, popona, coopertio. Takie pokryte wozy kosztowały do Io grzywien.

Słowa kluczowe: Polska, X-XVI w., pojazdy, ich nazwy, konstrukcja, ceny

Pojazdy służyły do transportu ludzi, zwierząt, towarów oraz wielu innych rzeczy i dlatego towarzyszą człowiekowi od dawien dawna w jego codziennej pracy, w podróży i na wojnie (Russocki 1965: 243-268; Buczek 1967: 255-268; Rutkowska-Płachcińska 1978: 204-223; Matuszewski 2002: 253-267; Wrzesiński 2002: 217-246; Szymczak 2008: 103-I16; Robak 2009: 175-188). Ich znaczenie dla ludzkości przypominają nazwy konstelacji Małego Wozu i Wielkiego Wozu z Wozem Dawida na naszym nieboskłonie. 
Znamy także inne pojazdy wraz z ich woźnicami i nie tylko. Ich listę otwiera grecki Helios, który na złotym rydwanie, zaprzężonym w cztery białe konie, przemierzał ziemski dzienny nieboskłon, następny jest św. Eliasz, prorok podróżujący do nieba na ognistym pojeździe z ognistymi rumakami (IV Król. 2, II) (ryc. I), a zamyka ją zwykły drewniany, ale symboliczny dla czasów zaborów wóz Michała Drzymały (Cetwiński, Derwich 1987: 196-197; Kopaliński 1991: 479-48I). Natomiast nasze swojskie ziemskie powozy stanowiły nie tylko ważny element polskiego krajobrazu historycznego, ale były wręcz niezbędnym przedmiotem na polskich drogach, którymi podróżowali zarówno władcy, wielmoże i biskupi, jak i kupcy oraz wieśniacy.

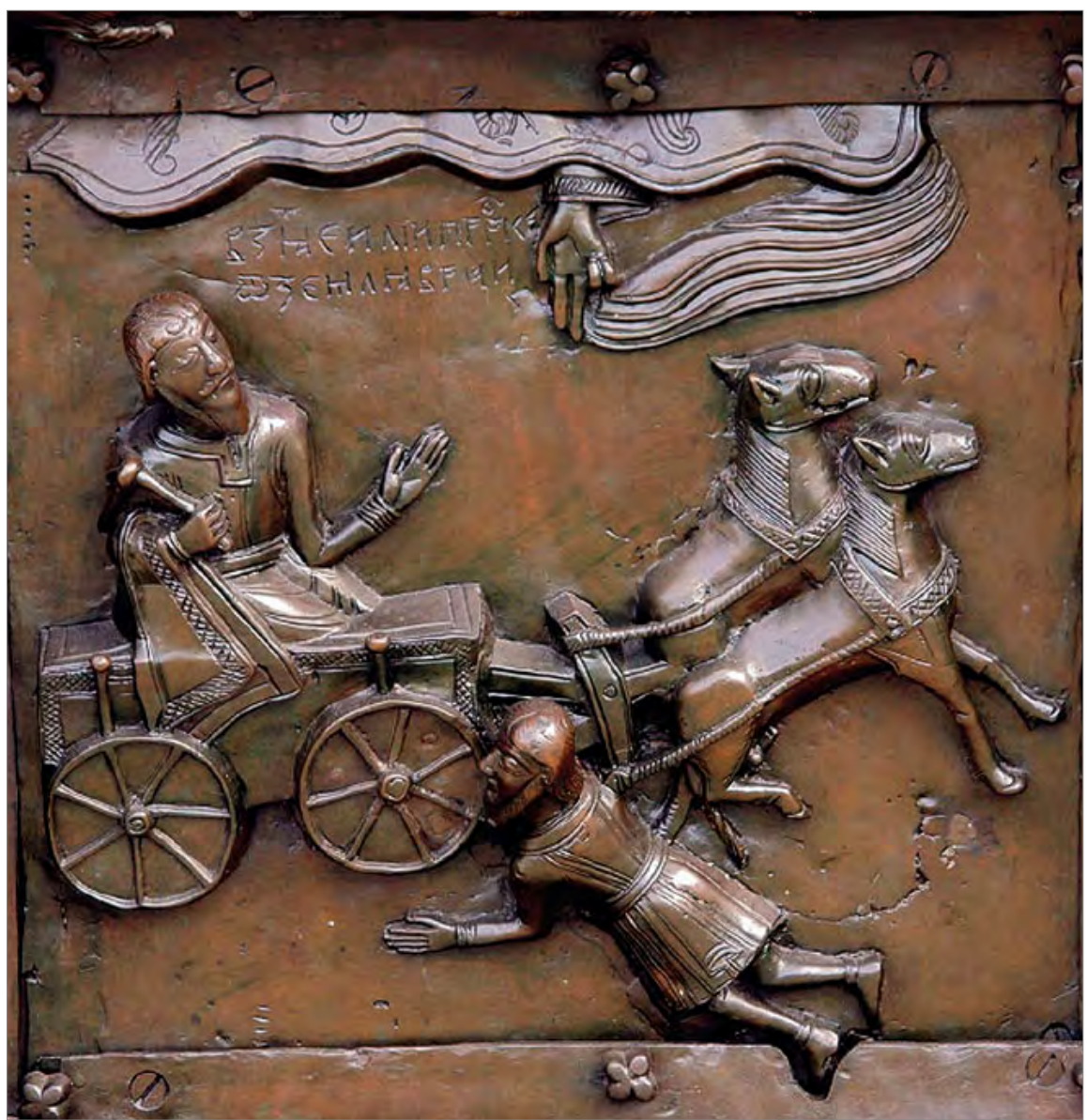

Ryc.1. Św. Eliasz podróżujący do nieba na wozie ciągniętym przez ogniste rumaki, Drzwi Płockie, poł. xı w. Domena publiczna. 


\section{Rodzaje pojazdów i ich nazwy}

Już Ibrahim ibn Jakub (Relacja... 1946: 54, I5I) w swej relacji z podróży do krajów słowiańskich zapisał, że ich królowie

podróżują wozami wielkimi, poruszającymi się i wzniesionymi na czterech kołach. W czterech rogach tych wozów są ustawione cztery mocne belki, z których zwisa na silnych łańcuchach kolebka (lectica) wyścielona brokatem, tak, że siedzący w niej nie trzęsie się podczas wstrząsów wozu.

Pojazdy, których nadwozia zawieszone były na pasach lub łańcuchach, używane były już w okresie rzymskim. Ich konstrukcje były zresztą różne. Dla wygody podróżowania biskupa św. Udalryka/Ulryka z Augsburga (zm. 973) na jego wozie (plaustri) umocowano na żelaznych pasach (in ferropendente) specjalne siedzisko na podwyższeniu - zapewne dla podkreślenia jego wysokiego statusu społecznego (Vita Sancti Uodalrici... 1993: 140; zob. Wółkiewicz 2012: 104). Zapewne o takim pojeździe z pasami (in curro appenso) prepozyta gnieźnieńskiego Mikołaja Strosberga wspomina Jan z Czarnkowa (1872: 713). Chyba w takiej karecie (curru a rotis pensili), gdyż w wozie wiszącym na kołach! (Bielski I856: 900; Plewczyński 2005: I45), wieziono schorowanego Jana Olbrachta podczas odwrotu spod Suczawy w I 497 r. w asyście chorągwi nadwornej.

Taka kolebka to pudto czterokotowej kolebki początkowo potożone na osiach, póżniej zawieszone na tańcuchach, wreszcie na linach i skórzanych pasach utwierdzonych do czterech stupków (Żurawska 1982: I8; Rutkowska 2012: 188). Łukasz Górnicki (2003: 139) do tej charakterystyki dodał jeszcze znajdujące się w niej stopnie, a przynajmniej jeden, na którym stał starosta lwowski Piotr Barzy - konwojując Halszkę Ostrogską z klasztoru na zamek lwowski w I559 r.

W I 419 r. Władysław Jagiełło podróżował z Poznania do Środy na wozie sporządzonym na ksztatt kolebki (in quadriga incunabuli modum fabricata), którą to quadrigam regis ciągnęły cztery konie, a idący pieszo dwaj ludzie w służbie królewskiej podczas burzy w gaju koło Tulczy nogami podtrzymywali boki karocy królewskiej od upadku (qui latera quadrige regie a cadendo euntes pedibus sustentabant) (Długosz 1982: 106; 1997: 102). W tym miejscu aż się prosi o przywołanie miniatury z kroniki Ulricha Richentala, na której taka sytuacja została zilustrowana i która zdobi okładkę książki pt. Samotrzeć, w kompanii czy z orszakiem? (ryc. 2).

$\mathrm{Na}$ listę kolejnych nazw na oznaczenie wozu Herbord (Herbordi Dialogus I974: 80, 86-87, I26, I4I; zob. Leciejewicz 1985: I08, przyp. 3), autor żywota św. Ottona z Bambergu, oprócz znanych już nam quadrigas et currus, wpisał ponadto vehicula i carrata jako środki transportowe. Pierwsza nazwa pojawia się później kilkakrotnie w rejestrach wielkorządcy krakowskiego Klemensa 


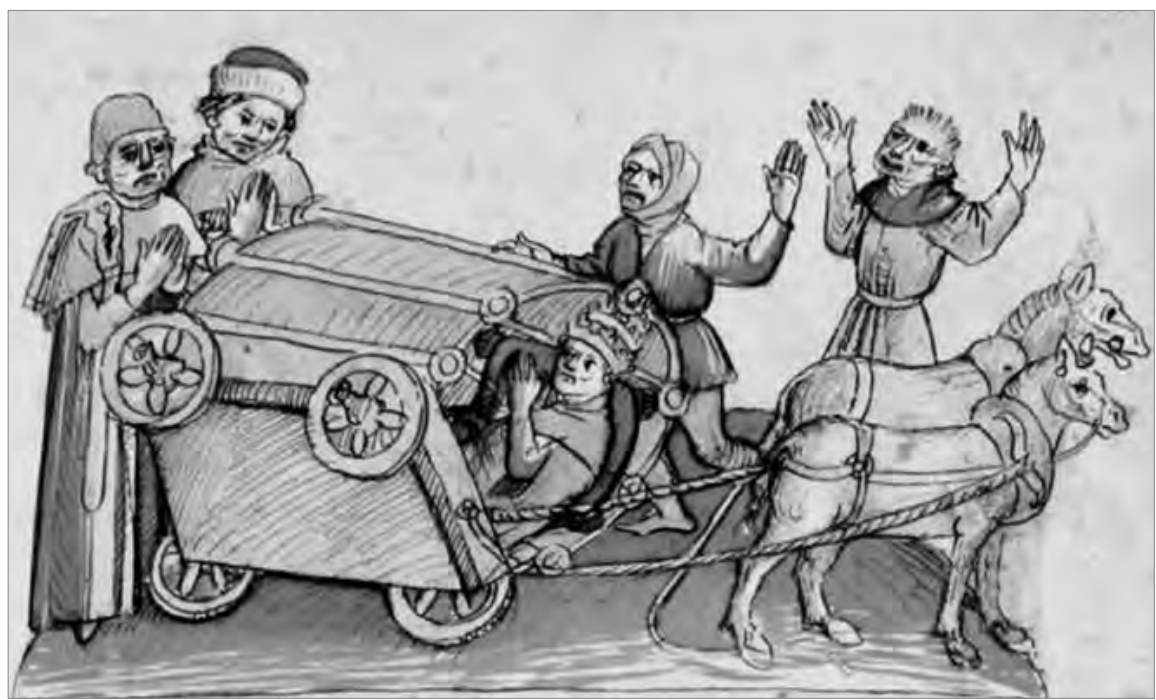

Ryc. 2. Wóz z kroniki Ulricha Richentala, Chronik des Konstanzer Konzils I4I4-I4I8, około I464, fol. 9. Domena publiczna.

Wątróbki. W I 420 r. czytamy w nich, że za vehiculis cum attinencijs eorum zapłacono Is groszy, a w innym miejscu znalazł się zapis o dwóch vehiculis do przewozu sieci i innych rzeczy za 20 groszy (Rachunki dworu... I896: 558-559). Dodajmy, że w jego rejestrach z I4I9 r. znalazł się także zapis o dwóch saniach (wehiculis alias sani) za 24 grosze, na których wieziono do Jedlni sieci z koszami do nich (Rachunki dworu ... 1896: 557; zob. Rutkowska-Płachcińska 1978: 213). A zatem vehiculum to nie tylko wóz!

Potwierdza to Jan z Czarnkowa (1872: 632-633), opisując ostatnią podróż Kazimierza Wielkiego do Krakowa z nieszczęsnych łowów w lasach pod Przedborzem we wrześniu $1370 \mathrm{r}$. Wymienił on znany i powszechnie używany currus, którym podróżował król do lasu na polowanie, ale dla rozgorączkowanego po wypadku władcy przygotowano vehiculum, do którego - zamiast koni - wprzęgli się wierni dworzanie i ostrożnie zawieźli go tym sposobem aż do klasztoru w Koprzywnicy. Wszystko to prawie wiernie powtórzył za nim Jan Długosz (1975: 434-435; 1978: 344-345), z tym że - jego zdaniem - to vehiculum nieśli rycerze na ramionach jak nosze.

Przytoczone przykłady potwierdzają słownikowe objaśnienie słowa vehicŭlum jako każdego środka przewozowego na lądzie i na wodzie (Jougan 1958: 719; Matuszewski 2002: 255, przyp. I0), ale nie tylko, skoro może być to nawet wehikuł czasu!

Natomiast zapisana przez Herborda carrata, pełna świeżych śledzi za denara (Leciejewicz 1985: 103), znalazła się także w wykazie danin składanych przez Słowian łużyckich klasztorowi w Nienburgu w połowie XII w., wśród których 
wymienia się również ryby, liczone nie tylko na kopy, ale nawet na wozy, gdyż 2 carrada piscium miał dostarczać jakiś bogaty Swati (Kodeks dyplomatyczny Ślaska... 1956: nr 27; zob. Labuda 1999: 132-133). W tym przypadku - podobnie jak słowo currus - carrata nie oznacza wszakże nazwy samego wozu, lecz także jego ładowność jako jednostkę masy (Jougan 1958: 93; Matuszewski 2002: 255, przyp. I0). Przypuszcza się, że chodziło tutaj o niewielki dwukołowy wóz (Stownik taciny średniowiecznej... 1960: 214; zob. Leciejewicz 1985: 103).

Zapewne zupełnie inaczej prezentowała się wygodna carretta, która w zaprzęgu sześciokonnym służyła Elżbiecie Łokietkównie i towarzyszącym jej ośmiu dwórkom podczas pobytu w Rzymie w 1343 r. (Kutyłowski 1974: 730-731; Sroka 1999: 47; Dąbrowski 2007: 56; Rutkowska 20I2: I88, przyp. 39).

Takie same lub o podobnej konstrukcji pojazdy znajdujemy w rachunkach dworskich królowej Jadwigi i Władysława Jagiełły (Rachunki dworu... 1896: 16I, I65, I82, 211, 338; Przezdziecki I854: I45, I47; Rutkowska-Płachcińska 1978: 212; Rutkowska 20I2: I87-188). Dominuje w nich królewska asseda dicta 'colebca', która W I394 r. kosztowała aż 8 grzywien (Rachunki dworu... I896: 2II). W I 416 r. opłacono woźnicę, który najpierw cum curru regine, a później cum currukolebka regine (Podwody kazimierskie... 1909-1913: 405) (Anny Cylejskiej) jeździł do Proszowic, zapewne już po jej śmierci (zm. 20-2I III I4I6). To Łukasz Górnicki (2003: 66) napisał, że za jego czasów (w I553 r.): król [Zygmunt II August] i arcyksiążę [Ferdynard] na konie, a królowa [Katarzyna] do kolebki wsiedli (zob. Dyakowski I9II: 83; Bystroń 1994: 533). Ale wcześniej kolebka służyła zarówno paniom, jak i panom. Zresztą sam Górnicki później odnotowat, że Zygmunt August, żegnając siostrę Katarzynę i jej męża Jana III Wazę w I562 r., wsiadt do kolebki z królewną, a książę finlandzkie na koniu jechat (2003: 154). W takiej sytuacji było to jednak zrozumiałe!

Liczne zapisy w sprawie kolebek królewicza Zygmunta Jagiellończyka zawierają także rachunki z okresu jego pobytu na Śląsku. Sporo wydano wtedy na różne przedmioty ad kolepczanye i ad kolepczane, czyli do kolebek, głównie na ich naprawę i uzupełnianie wyposażenia (a reformatione kolepki) (Jagelló Zsigmond... 20I4: indeks, 4I8). W $1506 \mathrm{r}$. wymieniano w nich rzemienne pasy (pro redis novis 'rzemyenne' ad 'kolepkam') (Jagelló Zsigmond... 2014: 323), w I505 r. zaś kupiono sukno i kobierce do pokrycia i wymoszczenia ich wnętrza (propanno nigro ad loco et 'kopyercze' [...] 'na zaloba' [...] ad 'kolepkam') (Jagelló Zsigmond... 2014: 213).

Podobną do kolebki, albowiem podkolebkę (assedem alias podkolepka) - może z racji jej mniejszych rozmiarów - wysłaną przez Jagiełłę w I 42 I r. do Sandomierza i asedem podkolepka w I 423 r. dla królowej Zofii Holszańskiej, znajdujemy w wykazach podwód z podkrakowskiego Kazimierza (Podwody kazimierskie... 1909-1913: 4I5, 423). Odnotowano w nich także inne wozy królewskie, jak: currus regis, currus reginae, currus longus reginae, a ponadto: currus scholtisky, curriculus metropolitano oraz wojenny currus expeditionales (Podwody kazimierskie... 1909-1913: indeks, 455). 
Łukasz Górnicki (2003: 127), opisując wyjazd królowej Bony z Polski, napisał, że

wyprawiła przed sobą królowa Wilgę, starostę ostrołęckiego, z wozy skarbnymi nałożonymi srebrem, złotem i drogimi klejnoty, których wozów było dwadzieścia i cztery, a w każdym poszosne woźniki.

Takie wozy skarbne odnotowujemy już wcześniej. W podwodach kazimierskich (1909-1913: 408) w I4I7 r. zapisano wysłanie do Proszowic currum cum thesauro regis. Wbrew swojej nazwie, wozami skarbnymi - w dzisiejszym rozumieniu przewożącymi majątek w postaci drogocennych przedmiotów - zazwyczaj transportowano głównie sprzęt podróżny właściciela (Gloger 1903: 242; Dyakowski 1911: 65-66). Pół wieku wcześniej Jan z Czarnkowa (1872: 657) odnotował taki wóz skarbny (currus cum suo thesauro) Jaśka Kmity oraz wozy wieśniaków (currus rusticorum), na których napastnicy z Nakła w marcu 1383 r. odwieźli łupy zagrabione sędziemu kaliskiemu Mikołajowi z Chomiąży (1872: 728). Ale dla Jana z Czarnkowa (1872: 646) prawie każdy wóz - oprócz odnotowanego wyżej vehiculum - to currus; także te cztery, pokryte czarnym suknem/kirem i wszystkie z czterema końmi w zaprzęgu, które uczestniczyły w orszaku żałobnym podczas egzekwii po śmierci Kazimierza Wielkiego w 1370 r.

Niekiedy zwykły wóz był przystosowany do zadań specjalnych. Jak pisze Łukasz Górnicki (2003: 170-171), ze względu na bóle artretyczne nóg i rąk, które dokuczały Zygmuntowi II Augustowi, swoją ostatnią podróż w 1572 r. z Warszawy do Knyszyna król odbył w łóżku, wstawionym na wozie do tego celu specjalnie przysposobionym. Podał on także (2003: I45), iż skazanego na śmierć niejakiego Wójcika za pogróżki przeciw królowi w 1562 r. wtóczono po mieście na tubie, a po wtóczeniu ścięto. Był to pojazd wyplatany łubą drzewną - tzw. dartką z kory wiązu, lipy lub sosny i dlatego kojarzy się on z dużą łubianką.

W rachunkach Zygmunta Jagiellończyka wielokrotnie występuje currus pythny (piczny), który naprawiano, dokupowano do niego różne części i reperowano jego koła (Jagelló Zsigmond... 20r4: indeks, 404). Odnotujmy w tym miejscu, że wozy piczne są tak nazywane od słowa pica - żywność i przeznaczone głównie do transportu żywności, tak jak słowo picować oznaczało zdobywanie żywności (Stownik polszczyzny..., t. xxIv: 17).

Do przewozu królowej i króla służył również reynwayn, czyli rydwan, zapisany w 1393 r. jako lekki wóz za 2 grzywny do przejażdżki z wygodnym siedzeniem z oparciem (pro curru leui dicto 'reynwayn', cum reclinario dicto 'poklath') (Rachunki dworu... 1896: 158; zob. Przezdziecki 1854: 148; Kręt 1987: 186; Rutkowska 2012: 188). Potwierdza to zapis w średniowiecznym słowniku, że wóz podróżny jako carpentum $=$ currus poklath $=$ rydwan $=$ pilentum to kryty wóz dla dam (Erzepki 1907-1908: 72; Stownik staropolski..., t. VI: 314; Jougan 1958: 509). W wyprawie ślubnej Zofii 
Jagiellonki w I555 r. znalazło się dziewięć powozów, a to rydwan oraz cztery kolebki i tyleż samo wozów zaprzęgowych (Brzeska 2009: I43-I44). W wozowni Elżbiety Habsburżanki znajdowała się kolebka królowej, kolebka panieńska dla dwórek, rydwan panieński i cztery wozy skarbne czterokonne - tzw.poczternie. Jej siostra Katarzyna - w świetle spisu z około 1565 r. - dysponowała kolebką wielką, kolebką łowczą, dwiema kolebkami panieńskimi, dwoma rydwanami panieńskimi, rydwanem doktorskim dla lekarzy, rydwanem kapłańskim, czterema wozami pościelnymi, czterema wozami skarbnymi na sprzęty podróżne i trzema wozami giętymi. Pojazdem reprezentacyjnym była kolebka, podróżnym - rydwan, wozy skarbne zaśi pościelne to wozy bagażowe (Marchwińska 2008: 129).

Po drogach poruszały się także rydwany transportowe - zapewne czterokolowe - i takie wozy, ale kupieckie, zwane rynvani, przejeżdżały przez Ropczyce w myśl dokumentu z I453 r. (Matricularum... 1908: suppl. nr I55; zob. Stownik staropolski..., t. viII: 63). Rydwany, oprócz wozów picznych, czyli prowiantowych, a ponadto kolas i wozów kotczych, wymienił hetman Jan Tarnowski w swoim Consilium rationis bellicae (1987: 53, 167, 173). Za Zygmuntem Glogerem (1902: 54-55) powtórzmy, że słowa kotczi kotczy to dawne określenia kocza - zapewne proweniencji węgierskiej - jako krytego lub półkrytego wozu służącego do wożenia rzeczy, person, potrzeb, jako u nas kotczy pospolity we 2, we 4 konie (Bystroń 1994: 537; Bołdyrew 2016: 126).

Trudno się więc w tym miejscu oprzeć, aby nie przytoczyć złośliwej charakterystyki, sformulowanej przez Stanisława Sarnickiego w Ksiegach hetmańskich (2015: 97), wozów prowadzonych przez szlachtę na wojnę:

Jeden by miał wóz skarbny do toczenia obozu dobry, drugi kotczy, trzeci wiera koliasę. Cośby tu była za ozdoba, co za porządek, co za pośmiech nieprzyjacieliowi.

Na zakończenie tej części dodajmy, że w I 419 r. odnotowano wozy alias 'taki, służące chyba do transportu narzędzi rolniczych (Rachunki dworu... I896: 559). Może tak nazywano zwykłe wozy, ale wiozące taki ładunek, albo były to wozy przystosowane do ich przewozu - coś w rodzaju dużych taczek?

\section{Konstrukcja pojazdów}

Wczesnośredniowieczne pojazdy miały w zdecydowanej większości konstrukcję drewnianą i były wyposażone częściej w jedną, rzadziej w dwie pary małych kół szprychowych z drewnianą obręczą, bądź tarczowych - wycinanych z pnia drzewa - kół bosych, gdyż bez żelaznych obręczy (Dobroński 1981: 521; zob. Stownik polszczyzny..., t. II: 343; Robak 2009: 179-180). Taki bosy wóz - tak samo jak bosy koń, to koń niepodkuty - odnotowano jeszcze w I605 r. w Sieradzu (AGAD, Księgi miasta Sieradza, ks. I4: k. 277-278). 
W taryfach celnych z XIII-XV w. wymienia się wozy większe, zwane niemieckimi, i mniejsze, określane jako polskie (Rutkowska-Płachcińska 1978: 210). Wóz z pielgrzymami w hornigowskiej wersji Legendy ślaskiej o św. Jadwidze z I 45I r. posiada cztery koła, z których wszakże dwa tylne są wyższe od przednich, co - jak się przyjmuje - jest typowe od XIV w., a także obudowę w postaci kosza z wiklinowej plecionki (Legenda śląska... 1967: il. 52; Matuszewski 2002: 259) (ryc. 3), a taki przykoszek odnotowano w rachunkach podskarbiego Hinczki w 1394 r. (Przezdziecki I854: I48; Rachunki dworu... I896: 213). Przypomina on współczesny typ wozu określanego jako krakowski i który identyfikowany jest ze wspomnianym wyżej wozem polskim (Currus Polonicalis) z dokumentu ugody celnej księcia łęczyckiego i kujawskiego Kazimierza Konradowica z krzyżakami w 1252 r. (Preussisches Urkundenbuch...: 199, nr 260; zob. Mitkowski 1968: 89). Był on dobrze dostosowany do złych dróg o zróżnicowanej wysokości wyboistych podłoży. Jego burty stanowiły lekkie drabiny utrzymujące półkoszki z wikliny. W I 46I r. takie polukoschky kosztowały is groszy (Rachunki wielkorządowe... 1909-1913: 490, nr 382). Wadą takiego wozu była ruchoma orczyca, na nierównej drodze powodująca obijanie boków konia dyszlem, ale jednocześnie łagodząca szarpnięcia i wstrząsy (Grabowski 1963: 59; Kołyszko 2007: 196-197; por. Robak 2009: 178). Natomiast słynnego tura, gdyż ukazywanego chyba w każdym podręczniku szkolnym i akademickim oraz we wszystkich pracach z dziedziny techniki i kultury materialnej, a nawet dyplomacji, transportowano do Konstancji dwukołowym wozem drabiniastym - jak ukazuje miniatura w kronice Ulricha Richentala (Samsonowicz 1991: 273; Matuszewski 2002: 259).

W ilustrowanej Legendzie ślaskiej w kodeksie hornigowskim z I 45I r. czterokonny wóz z przykoszkiem pomieścił osiem osób (nie znalazłem dziewiątej, którą wyliczyła monografistka Legendy śląskiej (1967: il.52), zresztą tylko siedmiu podróżnych znajdujemy w kodeksie ostrowskim z I353 r.), ale i tak wystarczająco dużo, aby potwierdzić ładowność takiego dwukonnego wozu na maksimum $700 \mathrm{~kg}$. Cięższe wszakże wozy furmańskie, przede wszystkim o silniejszej konstrukcji, z czterema lub więcej końmi w zaprzęgu, mogły zabierać nawet do I, 5 t (Poklewski 1979: I3; Matuszewski 2002: 259). Był to zapewne typ reyse wagen, jak nazywano wozy w inwentarzach oliwskich z XVI w. (Dąbrowski i975: I44).

Szerokość wozów wynosiła od 90 do IIs cm (Rutkowska-Płachcińska 1978: 213; Poklewski 1979: 13; Niesiołowska-Wędzka 1980: 595; Dobroński 1981: 521), ale dla okresu wczesnośredniowiecznego podaje się aż I,5 m, ich długość wynosiła zaś 150-160 cm (Robak 2009: 179).

Wozy były początkowo łączone na sztywno, tak samo osadzano w nich koła. Ważną innowacją - najpóźniej od XIV w. - było zastosowanie obrotowego układu kierowniczego, polegającego na ruchomym łączeniu przedniej osi wraz z dyszlem - tzw. kierownikiem - z nadwoziem. Dzięki takiemu ruchomemu przodkowi 


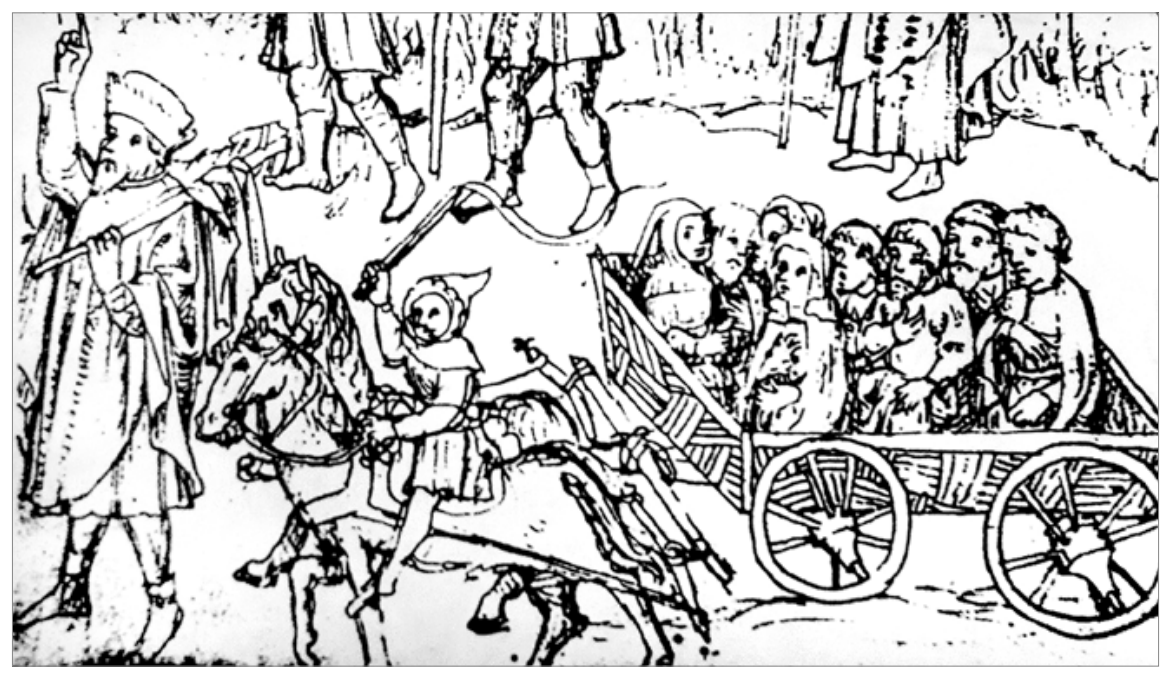

Ryc. 3. Wóz z pielgrzymami do grobu św. Jadwigi w Trzebnicy w hornigowskiej wersji Legendy śląskiej o św. Jadwidze z I45I r., wg Legenda śląska... I967: il. 52.

uzyskano większą zwrotność wozów, cechę ważną zwłaszcza w wielkiej kolumnie pojazdów, a także ładowność do 700-750 kg. Dotychczas używano dwuosiowych wozów z orczykiem i postronkami, nieraz z dyszlem, obciążonych do $500-600 \mathrm{~kg}$, albo korzystano z wozów jednoosiowych, ale kosztem wielkości bagażu tylko do $250-300 \mathrm{~kg}$. W XIV w. wraz z upowszechniającym się okuwaniem stelażowych elementów konstrukcyjnych wozu oraz wzmacnianiem kół metalowymi okuciami i żelaznymi obręczami obciążalność wozów dwuosiowych wzrosła do 800-1000 kg (Kwiatkowski 20I6: 476-477). W XVI w. zaczęto stosować skośne ustawienie kół wozu w stosunku do nawierzchni, zwiększające jego elastyczność. Poprawę trwałości wozu przyniosły żelazne osie i tuleje w otworach piast (łożyska smarowano głównie łojem).

Nawiązując do sprawy wozów okuwanych żelazem, odnotujmy, że w I506 r. z kasy Zygmunta Jagiellończyka wypłacono 4,5 grosza kowalowi w Prudniku za okucie kolebki żelazem (fabro a cudendis ferramentis a kolepka) (Jagelló Zsigmond... 20I 4: 258).

Nie było to zlecenie nadzwyczajne, gdyż takowe prace leżały w możliwościach wielu kowali. W taksie łęczyckich kowali z i564 r. (AGAD, Metryka Koronna, ks. 26: k. 797) czytamy, że

od kowania woza drewnego, gdi ktho da swoie zelazo zloty, a kiedy kowal swym zelazem okazowacz ma myecz sobye każdy, kto she stharguye. 
W następnym roku (AGAD, Metryka Koronna, ks. 26: k. 1056-1056v) powtórzono, że od kowania woza drewniego kiedi kto zelazo da swe gr 24, a kiedy zelazo kowalowe thedy yako starguje.

Jakkolwiek powyższe zapisy są trudne do interpretacji w sprawie wielkości kowanych części w wozie to jednak sugerują okuwanie jeszcze innych jego części niż tylko kół, o których nie ma nawet mowy! (Bołdyrew 2017: 117).

Nadwozia pojazdów jednoosiowych były konstruowane z desek lub wikliny w kształcie krótkiego prostokąta. W wozach dwuosiowych miały one zazwyczaj postać mniej lub bardziej wydłużonego prostokąta i burty - drewniane lub wiklinowe albo drabiniaste - osadzone pionowo lub lekko rozwarte do góry.

Wartość pojazdów zależała w dużej mierze od konstrukcji i wytrzymałości ich kół. W statucie stelmachów i kołodziejów (currificum et rotificum) krakowskich z is I r r. zapisano, że sztuka mistrzowska dla kołodziejów polegała na wykonaniu fire rade zcw eynem rynnwagen zcw der kawflewte wagen wnde czwe radir zcw grossem furmanns wagen (Prawa, przywileje i statuta... I885: $\mathrm{nr} 309, \$$ I3 $)^{1}$.

W statucie cieśli i kołodziejów (carpentariorum et rotificum) krakowskich z I555 r. (Prawa, przywilejei statuta... 1885: nr 490, \$ I1; zob. Bołdyrew 2017: I14-II5) zapisano, że

stelmach bendzie powinowat vczinicz wassąg $s$ krzyniami y $s$ kratami, zaś kolodziei ma vczinicz sterzi kola do ridwana kupieckiego a dwie kola do wielkiego fvrmaniskiego wozu.

Przyjmuje się, że wasąg to czterokołowy powóz bagażowy i podróżny, odkryty z nadwoziem drabinkowym, opartym bezpośrednio na osiach, z wyplatanymi bokami z wikliny lub jałowca (Dobroński 1981: 522; por. Bołdyrew 2017: 117).

Wozy jednoosiowe miały zaprzęg I-2 koni, lżejsze dwuosiowe 2-3, cięższe 3-4 koni lub nawet więcej i były obsługiwane przez woźnicę i jednego lub nawet dwóch pachołków, z których jeden dosiadał wówczas konia z przedniego zaprzęgu jako tzw. korytarz/foryś (Kołyszko 2007: 193-194; Kwiatkowski 2016: 477).

Niekiedy wszakże stelmachom zezwalano robić i montować koła, ale w produkowanych przez nich wozach - jak we Lwowie w is Is r. Podobnie było w Lublinie, gdzie w I545 r. Janowi Miziołkowi przyznano nie tylko dyplom w zakresie sztuki stelmacha, ale także kołodzieja (praeter artem curruum faciendorum etiam artem rotarum exercere facultas datur) (Bołdyrew 2017: 113).

1 Kodeks Baltzara Behema ma wersję: 4 rade czw eynem rynwagen vnd II reder czw grosem furmans wagen; zob. Bołdyrew 2017: II 4 . 
Wozy z kosami - mocowanymi zazwyczaj do kól - znano od starożytności i wykorzystywano je głównie na polach bitewnych. Wszakże w I487 r. Barbara, córka chorążego sieradzkiego Marcina z Niewiesza koło Uniejowa, wdowa po Stanisławie z Kobieli, żądała od swych bratanków, Marcina i Jana, wyprawy, tj. oprócz sukna, futra i czepców, także currum falcatum cum veredariis (AGAD, Księgi ziemskie szadkowskie, ks. 6: s. 479), czyli wozu uzbrojonego w kosy z końmi. Inne panie zadawalały się wozem, ale tylko tzw. żelaznym, tj. z kołami okutymi żelazem, którym przewoziły swoją wyprawę do domu męża, ale wóz z kosami dawał bogatej wdowie większe poczucie bezpieczeństwa i prestiż z racji jego posiadania (Szymczakowa 200r: 144-I45).

\section{Ceny pojazdów}

W przedstawionym wyżej materiale ceny pojazdów kształtowały się na różnym poziomie, albowiem dotyczyły różnych rodzajów, w tym egzemplarzy prostych, gospodarczych, pojazdów podróżnych, o różnej zresztą konstrukcji i wielkości oraz z różnym wyposażeniem - normalnym, czyli w zasadzie powszechnie używanych, i specjalnym dla dostojnych i wielkich tego świata.

Cena wozu zależała od jego wielkości, oprzyrządowania i przeznaczenia. W rejestrach wielkorządcy krakowskiego Klemensa Wątróbki z I 419 r. czytamy, że pro curru cum suis attinencijs dla psiarczyków zapłacono 3 wiardunki, tj. 36 groszy. W następnym roku, także dla tych służb, pro curru eisdem canistis cum suis attinencijs zapłacono tylko 32 grosze (Rachunki dworu... I896: 558, 559). Nie były to jednak wozy mocno obciążone, skoro w zaprzęgu miały tylko jednego albo dwa konie.

W 1393 r. currifex z podkrakowskiego Kazimierza otrzymał jedną grzywnę, czyli 48 groszy pro curru (Ksieggi radzieckie kazimierskie... 1932: 290). W I416 r. na roczku pyzdrskim stanęli Bartosz z Koźmina i Stefan z Trąbinka m.in. w sprawie wozu za kopę (Kodeks dyplomatyczny Wielkopolski... 1989: nr 782), czyli 60 groszy. Najczęściej jednak ceny całych wozów w XV w. kształtowały się na poziomie 2-3 grzywien. W I 475 r. currifici alias stelmach za każdy z czterech wykonanych przez niego wozów curribus pyczne zapłacono po 3 grzywny (AGAD, Archiwum Skarbu Koronnego, dz. I: Rachunki królewskie, nr I8: k. 269).

Jak pamiętamy, królewska asseda dicta 'colebca' w I394 r. kosztowała aż 8 grzywien (Rachunki dworu... I896: 2II) i jest to najdroższy pojazd odnotowany w źródłach do XVI w. Do przewozu królowej i króla służył również tzw. reynwayn, czyli rydwan, zapisany w I393 r. jako lekki wóz za 2 grzywny do przejażdżki z wygodnym oparciem lub siedzeniem i pokryciem. Różnica w cenach tych pojazdów jest tu ogromna, może ze względu na ich konstrukcje i wyposażenie?!

W I487 r. odnotowano currum in valore trium marcarum cum omnibus attinenciis, a więc wóz z całym wyposażeniem za 3 grzywny (Acta officii consistorialis Leopoliensis..., 1927: $\mathrm{nr}$ 1861). 
$\mathrm{Z}_{\text {I505 }}$ r. dysponujemy kosztorysem wykonania wozu (in extruendo curru), o którym niejaki Jan Schalner informuje rajców bardiowskich. Stemachowi dano 42 grosze (currifici dedi Polonicam marcam minus vi grossos), kowalowi całą grzywnę (fabro dedi unam Polonicam marcam, facit I, s florenum), tj., licząc florena po 32 grosze, za okucie kół zapłacono I2 groszy (quivis modicum ferri apposuerit pro rothis, dedi duodecim grossos), co razem wyniosło IO2 grosze, czyli - jak czytamy w podsumowaniu tego rachunku - 3 floreny i 6 groszy (Dokumenty polskie z archiwów... 2006: nr 644).

W największym stopniu ceny pojazdów uwzględniają oficjalne cenniki państwowe i cechowe, ale takimi dysponujemy w zasadzie dopiero od XVI w.

W cenniku wojewody krakowskiego Piotra Kmity z 1538 r. (Cennik wydany... I884: 358-359) znajdujemy cztery rodzaje najbardziej popularnych wyrabianych wozów. Pierwszy to rydwan z dwukonnym zaprzęgiem (currus alias Ridwan super duos equos ad cubitos) za 2 floreny, drugi średni za 3,5 florena i trzeci wielki rydwan za 5 florenów. Również na 5 florenów był wyceniony czwarty wóz specjalny - dla zaciężnych - z całym oprzyrządowaniem, na które składały się: kosz z wagami, orczyki, okute żelazem koła i pokletnica, czyli poklat, jak nazywano przykrycie wozu, tzw. budę (currus stipendiariorum alias cum omnibus apparamentis, videlicet scirpeis szwagamy, orcziky, skoly kowanemy y poklyethnycza).

Według taryfy z i56I r. dla województwa krakowskiego dwukonny currus ridwan - mający 2,5-3 łokcie (łokieć krakowski $=586 \mathrm{~mm}$ ), tj. około I 47-176 cm długości - został wyceniony na 2 floreny. Lecz już większy, czyli currus maior, był wart 4 floreny, ale currus magnus ridwan aż 6 florenów i tyle samo currus stipendiariorum cum omnibus aparamentis (Kilka zabytków ustawodawstwa... I895: 96). Nie był to zapewne całkowity koszt wozu z kołami, gdyż znajdujący się w tym samym dokumencie cennik tamtejszych kołodziejów zawierał ich ceny także do różnego rodzaju wozów, jakkolwiek nie tak samo nazwanych jak u stelmachów. Za cztery koła ad currum minorem 20 groszy, ad currum maiorem i ad currum skarbici po 24 grosze, do wozu zaś zwykłego, prostego (ad currum simplicem) tylko I8 groszy (Kilka zabytków ustawodawstwa... I895: 96).

Interesujące dane pod względem wartości wozów posiada taryfa cen dla województwa krakowskiego z 1565 r., która uwzględnia więcej niż poprzedni cennik rodzajów pojazdów i podaje ich rozmiary. I tak dwukonny rydwanik na 3-3,5 tokcia (ok. 176-200 cm) kosztowal 2,5 florena; rijdwan wientszij na 4 tokcie (ok. $234 \mathrm{~cm}$ ) - 3 floreny; rijdwan wielkij na 4,5-5 tokci (ok. 264-293 cm) - 4 floreny. Dochodziły do tego zapewne cztery koła, które - wszystkie bose, tj. niekowane - kołodzieje wycenili następująco: do rydwanu mniejszego na 24 grosze, do rydwanu wielkiego na 28 groszy i do wozu skarbnego albo furmańskiego na 32 grosze. Dla porównania, wóz wojenny ze wszystkimi potrzebami wyceniono 
na 8 florenów (Taryfa cen... I89I: 3II-3I2), ale różnił się od tamtych pod wieloma względami, gdyż już z kołami i to okowanymi oraz półkoszkami!

Warto odnotować, że w i 475 r. pewien coszarz otrzymał jedną grzywnę za wykonanie sześciu koszy do wozów picznych (ad currus pyczne) i I2 kyellis na wozy skarbne (ad currus thezauri) (AGAD, Archiwum Skarbu Koronnego, dz. I: Rachunki królewskie, nr I8: k. 269), tj. kielli lub killi - jak nazywano kiedyś pojemniki na drobny bagaż (Stownik staropolski..., t. III: 275; Stownik polszczyzny..., t. X: 300; (Jagelló Zsigmond... 2014: 420, indeks, 'kyelle’).

Wozy zaopatrzone były w latarnie, po 2 skojce za sztukę (Item 4 sc. vor 2 leteren uff dy bussenwagen) (Nowa ksiega rachunkowa Starego Miasta Elblaga... 1989: nr I 449). Właśnie taką latarnię miał jeden z wozów na znanym obrazie przedstawiającym bitwę pod Orszą (Żygulski jun. 1999: 259, ryc. I).

Jednym z najważniejszych i chyba najwrażliwszych na zepsucie i zniszczenie elementów w każdym wozie były jego koła. W związku z tym warto odnotować uwagę Anzelma Gostomskiego (I951: 35), z jego trzeciego listu w Gospodarstwie, żeby zadbać, aby kędy bednarz, tam drzewa suchego i obręczy wczas mieć. Od tego bowiem najczęściej zależała wartość koła i to do każdego pojazdu kołowego.

Znajdowane fragmenty kół wskazują, że były to koła szprychowe o obwodzie giętym z jednego kawałka drewna lub składającego się z kilku dzwon. Piasty w tych kołach były wydłużone i osadzone w drewnianych osiach. Drewniane osie były stosowane w wozach chłopskich jeszcze do niedawna (Matuszewski 2002: 258). Średnica znanych kół z Opola wahała się w granicach $60-90 \mathrm{~cm}-\mathrm{w}$ zależności od rodzaju wozu. Ich wytrzymałość obliczono na $1200 \mathrm{~kg}$ na trasie około $200 \mathrm{~km}$ w przypadku równej drogi i bez nadmiernego obciążenia (Dembińska 1978: 245).

W I 475 r. kołodziejowi/rotifici zapłacono I,5 grzywny za I2 wykonanych rotis na zapasz, tj. po 6 groszy za każde (AGAD, Archiwum Skarbu Koronnego, dz. I: Rachunki królewskie, nr I8: k. 269), ale w I 489 r. jedno koło kosztowało aż I8 groszy (AGAD, Archiwum Skarbu Koronnego, Oddział 86, nr 5: k. 80). W cenniku Piotra Kmity (Cennik wydany... I884: 359) z I538 r. wyszczególniono koła od 12 do I8 groszy, z czego najtańsze były przeznaczone do wozu małego, za is groszy do wozu zwykłego, za i6 do wozu wielkiego, po I8 groszy zaś ad currum alias skarbny. Według krakowskiej taksy wojewodzińskiej z 156I r., do małego wozu można było kupić cztery koła za 20 groszy, natomiast do większego i skarbnego kosztowały one 24 grosze (Kilka zabytków ustawodawstwa... I895: 96). Mamy więc znaczną rozbieżność w cenach, która wynosi od 5 do I8 groszy. Dysproporcja ta wynikała $\mathrm{z}$ różnic w konstrukcji kół stosowanych w różnych pojazdach, w zależności od przeznaczenia i ciężaru przewożonych przedmiotów. Wozy do transportu ciężkich bagaży miały zazwyczaj żelazne obręcze na kołach i osie oraz tuleje w otworach piast i sześć szprych. 
Wartość kół podnosily koszty żelaza na obręcze do nich (pro ferro ad falcastra alias za obraczky) za 6 groszy, opłaty za ich okucie (a confabricacione earundem rotharum) dla kowala w wysokości 24 groszy i za osie (pro axibus alias ossy et snycze) stelmachowi I grzywnę (Rachunki wielkorzadowe... 1909-1913: nr 396-397, 420). W świetle rachunku z I 408 r. koła zwykłe kosztowały po 4 grosze, natomiast z żelazną obręczą aż Is groszy (Najstarsze ksieggi i rachunki miasta Krakowa... 1878: 28I). Według zapisu z I 489 r. kowal Gromek ab obferacione alias od okowanija jednego koła brał 26 groszy (AGAD, Archiwum Skarbu Koronnego, Oddział 86, nr 5: k. 79v). Koła okute żelazem i szyny do ich okucia odnotowują również rewizje zamkowe. W I509 r. we Lwowie znajdowały się m.in. 34 żelazne blachy do okowania kół, czyli lamina ferri alias szyny a notis (Górski 1902: 222). Takie szyny do okucia kół wymienia się także w rachunkach królewskich z 1472 i 1475 r. (Rachunki królewskie... 1960: 75).

W kołach ważnym elementem były także osie (Robak 2009: 178-179). W świetle taksy kowali łęczyckich z $1565 \mathrm{r}$. ich montowanie, czyli od osiowania woza prosthego zbuxe spodoski y okrom poduskow, yako ktho starguje (AGAD, Metryka Koronna, ks. 26: k. $1056-1056 \mathrm{v})$.

Interesujące są także rachunki za różne części do wozów, niekiedy z ich oprzyrządowaniem. W 1393 r. w Krakowie za osiem kół do wozów królewskich zapłacono 2I skojców, za osie i dyszle (pro axibus et temonibus) do nich dano 8 skojców, za części dictis barczcze (stąd barczyk - podwójny orczyk konny, czyli tzw. orczyca z hakami do mocowania orczyków; niem. Stelwaga) również 8 skojców (Rachunki dworu... I896: 157). Niebawem, w tym samym roku (Rachunki dworu... 1896: 273), zapłacono I6 skojców pro I curru cum IV rotis, axibus, podosky, buxe, redis, postronky, cordis canapeis, resina, secure in curiis. W I394 r. osie do wozu królewskiego kosztowały 9 groszy, zaś pro barcza, czyli orczycę do tego wozu dano 4 skojce (Rachunki dworu... I896: 191, 192). W 1395 r. czytamy (Rachunki dworu... I896: 216), że pro II cophinis [kosze] cum przykosky ad currum thezaurarum zapłacono 7 skojców, pro themonibus [dyszle], axibus [osie] et aliis instrumentis curruum, dictis bartcza [orczyce] ad currus zaś 12 groszy. Ważny zapis w tej sprawie zawierają także Rachunki wielkorządowe krakowskie z lat I46I-I462 i I47I (1909-1913: $489, \mathrm{nr} 363$ ), wymieniające stinvagy (niem. Stelwagi), czyli wspomnianą wyżej orczycę, oraz orcziky, drabini, ossi ad currum za I8 groszy.

\section{Wozy z nakryciem}

Pojazdy często posiadały tzw.poklat, jak nazywano materiałowe przykrycie wozu (Przezdziecki 1854: 147; Linde 1858: 283; Stownik staropolski..., t. VI: 314). Lekkimi powozami z półpoklatem podróżował Władysław Jagiełło. Dnia 6 września 1393 r. pro curru leui tunc temporis empto pro duccione diuersorum necessariorum 
versus Lamburgam za 2 grzywny, następnie 27 listopada 1393 r. pro I curru leui cum $I / 2$ poclad wysłanego królowi do Radoszyc zapłacono I,5 grzywny, a niecały rok później, gdyż 7 września I394 r., pro I curru paruo cum medio poclath, czyli też z półpoklatem, posłanego królowi do Dzierzkowa pod Radomiem z różnymi rzeczami zapłacono 2 grzywny (Rachunki dworu... 1896: 165, 172, 205). Półpoklat nie przykrywał zapewne całego wozu, lecz tylko jego część, zapewne tylną.

W rachunkach podrzęctwa korczyńskiego z 1389 r. zachował się interesujący zapis, że w niedzielę 4 kwietnia na wyraźny rozkaz króla wojewodzie litewskiemu Chomie(?) (dno Chome pallatino Lythwanie) wydano nowy wóz, całkiem żelazem obity i pokryty żółtym suknem podbitym płótnem (currum nouum ferro ex toto circumdatum, cum tectura flauea subducta tela), a w jego miejsce król kazał sporządzić nowy. I rzeczywiście, już 8 kwietnia pro vno curru nouo et ferro circumdato et cum tectura flauela tela subducta zapłacono 3,5 grzywny, tj. 168 groszy, ale $\mathrm{z}$ dopiskiem, że poprzedni był lepszy (quod adbuc meliorem currum dnus Choma aput dnum procuratorem recepit) (Rachunki dworu... I896: 95, 96). W takim razie najdroższy był królewski currus cum attinenciis suis z marca I394 r. za Io grzywien (Rachunki dworu... 1896: I83). Jego cena wszakże niewiele odbiegała od ceny krytego wozu (pro curru, tectura ipsius) dla Kachny, żony niejakiego Zabawskiego, za który w I394 r. z kasy królewskiej wypłacono 9 grzywien (Rachunki dworu... I896: 205). Był on droższy nawet od królewskiej kolebki - jak pamiętamy - za 8 grzywien, kupionej dziewięć tygodni później. Dobre wozy były zatem w cenie!

Z rachunków dworskich Jadwigi i Jagiełły wynika, że wszystkie przedmioty i sprzęty na potrzeby króla wożono na wozach przykrytych szarym, brunatnym, żółtym lub czarnym suknem (Kręt 1987: 186). W I46I r. pro panno super tecturam currus zapłacono 1,5 grzywny (Rachunki wielkorzadowe... 1909-1913: 490, nr 374). Natomiast na polecenie Zygmunta (Starego) w I505 r. we Wrocławiu kupiono cztery postawy czerwonego sukna wrocławskiego (panni rubei Wratislaviensis ad opony currum), po 2 floreny i i2,5 grosza za postaw, co dało 9 florenów i 20 groszy (Jagelló Zsigmond... 2014: 17I). W I506 r. zaś, w Wilnie pro panno rubeo 'lunskye' super 'popona' ad 'kolepka' dano ig florenów i 19 groszy (Jagelló Zsigmond... 2014: 370).

Interesujące dane w odniesieniu do rodzajów nakryć pojazdów zawierają rejestry podskarbiego Hinczki z I394 r. Za wóz dla księcia smoleńskiego Andrzeja - przyrodniego brata Jagiełły - zapłacono wtedy 2 grzywny; ale za 16 lokci sukna brązowego do jego pokrycia (pro tectura currus dicti ducis), po 7 groszy za łokieć, dano 2 grzywny 8 skojców, za 16 łokci zaś 'czewelich' ad subducendum eandem tecturam po 2 grosze, razem 16 skojców (Rachunki dworu... 1896: 187). Natomiast w I393 r. (Rachunki dworu... I896: I6I) zapisano, że za 42 tokcie (ok. 24 m) cwelichu (tele dicte 'czuelich') na pokrycie kolebki królewskiej zapłacono 84 grosze, licząc po I skojcu za łokieć. 
Cwelich (Zwilich) to gruba tkanina Iniana, konopna, bawełniana lub sporządzona z połączenia tych surowców, tkana najczęściej splotem wielorządkowym, w odróżnieniu od drelichu tkanego splotem rządkowym trzynitkowym (Zarys historii wtókiennictwa... 1966: 651, 672; Stownik staropolski..., t. I: 339; Stownik polszczyzny..., t. III: 715).

W I394 r. za 30 łokci płótna do podbicia takiego pokrycia na wozie królewskim (tele ad subducendum tecturam currus dni Regis) zapłacono 2I skojców i I kwartnik, czyli nieco ponad 42 grosze, gdyż liczono po jednym groszu i 4 denary za łokieć (Rachunki dworu... 1896: 204). Niebawem za takie pokrycie wozu (pro tectura currus dicta 'paluba') wiozącego rzeczy królewskie do Lwowa zapłacono zaledwie 2,5 grosza, ale w następnym roku pro tecturis curruum dictis 'palubi' ad currus dano 7 groszy, ale były to chyba dwie, a może nawet trzy sztuki (Rachunki dworu... I896: 204, 208, 218). W 1406 r. we Lwowie zapłacono 7 wiardunków (84 gr) za płótno na takie przykrycie wozu miejskiego (pro panno, videlicet ad poklat dato super currum ciuitatis) (Ksiegga przychodów i rozchodów miasta... I896: 30), w I 416 r. zaś z kasy miejskiej wyasygnowano aż 126 groszy na płótno do wozu (Pro panno ad assedam currus [...] vulgariter czum poclath), który wysłano do Nowego Miasta Korczyna (Ksiega przychodów i rozchodów miasta... 1905: 28). Natomiast w I47I r. za Ioo łokci płótna do pokrycia wozów (pro coopertinis currum) wydano tylko 67 groszy (Rachunki królewskie... 1960: 88). Różnica w kosztach zakupów - i to znaczna - wynikała zapewne z faktu przeznaczenia tych wozów, pierwszym bowiem podróżował król osobiście, następne służyły zaś do transportu jego rzeczy. Ale w I 420 r. za dwa vehiculis do przewozu sieci i innych rzeczy, videlicet palubi zapłacono Io skojców (Rachunki dworu... I896: 559). W związku z tym warto przytoczyć zapis z I46I r., kiedy pro tecturis ad currus alias za paluki zapłacono I2 groszy (Rachunki wielkorządowe... 1909-1913: 492, nr 4II) i postawić pytanie, czy aby nie chodzi tutaj o błędnie odczytaną pałubę (palubi?) lub pałąki?

Takie przykrycie wozu lub sań - tj. pałubę (Dyakowski 19ı1: 81; Przezdziecki I854: I48; Stownik staropolski..., t. VI: I2) lub znany nam już poklat - zawieszano zazwyczaj na solidnych żelaznych pałąkach, których trzy sztuki w 1393 r. kupiono za 2 skojce (pro ferimentis III curuatis, in quibus appenditur tectura cirrus) (Rachunki dworu... 1896: 182). Odnotujmy zatem, że dwuosiowy wóz w polu błękitnym w godle cechowym stelmachów w Kodeksie Baltazara Behema przykryty jest jakimś czerwonym materiałem naciągniętym na rozpiętych na jego burtach pałąkach (Bołdyrew 2017: 116). Również na obrazie przedstawiającym bitwę pod Orszą dwa wozy czterokołowe przykryte są czerwoną tkaniną, trzeci zaś żółtą, ale wszystkie narzuconymi na pałąkowate - ponoć drewniane - szkielety (Żygulski jun. 1999: 259, ryc. I).

W księdze wydatków podskarbiego Hinczki z 1394 r. znajdujemy szereg zapisów o wyposażeniu wozów, a to: pro I curru nouo cum attinenciis preter 'potclad' tantum 
et sporta [kosz] ac 'przycoszky' zapłacono grzywnę in skojców, czyli 70 groszy; za cztery nowe koła do tego wozu dano iz skojców, powrozy-liny łykowe do tych wozów kosztowały i skojca, powrozy-liny lniane? do nich (ad parandum lanvi et alias ligaturas), czyli wiązadła - I skojca (Rachunki dworu... I896: 213).

\section{Bibliografia}

\section{Źródła i wydawnictwa źródłowe}

ActaofficiiconsistorialisLeopoliensisantiquissima, t. I,I482-I489(1927), W. Rolny(wyd.), Lwów. Archiwum Główne Akt Dawnych w Warszawie (AGAD):

- Archiwum Skarbu Koronnego, dz. I: Rachunki królewskie, nr I8.

- Archiwum Skarbu Koronnego, Oddział 86, nr 5.

- Księgi miasta Sieradza, ks. I4.

- Księgi ziemskie szadkowskie, ks. 6.

- Metryka Koronna, ks. 26.

Bielski M. (1856), Kronika polska, t. I, K.J. Turowski (wyd.), Sanok.

Cennik wydany dla rzemieślników miasta Książ przez Piotra Kmitę, wojewodę krakowskiego w r. I53 8 (I884), B. Ulanowski (wyd.), „Sprawozdania Komisyi Językowej Akademii Umiejętności", 3 .

Długosz J. (1975), Roczniki czyli kroniki stawnego Królestwa Polskiego, ks. 9, J. Mrukówna (tłum.), Państwowe Wydawnictwo Naukowe, Warszawa.

Długosz J. (1978), Annales seu Cronicae incliti Regni Poloniae, ks. 9, Państwowe Wydawnictwo Naukowe, Varsaviae.

Długosz J. (1982), Roczniki czyli kroniki stawnego Królestwa Polskiego, ks. IO-II, J. Mrukówna (tłum.), Państwowe Wydawnictwo Naukowe, Warszawa.

Długosz J. (1997), Annales seu Cronicae incliti Regni Poloniae, ks. IO-II, Państwowe Wydawnictwo Naukowe, Varsaviae.

Dokumenty polskie z archiwów dawnego Królestwa Wegier, t. IV, (dokumenty z lat I5OI-IS20) (2006), S.A. Sroka (wyd. i oprac.), Towarzystwo Naukowe „Societas Vistulana", Kraków.

Erzepki B. (1907-1908), Przyczynki do średniowiecznego stownictwa polskiego, cz. I, Glosy polskie wpisane do tacinsko-niemieckiego stownika (Vocabularis ex quo) drukowanego w roku I49o, „Roczniki Towarzystwa Przyjaciół Nauk Poznańskiego”, 34.

Gostomski A. (195I), Gospodarstwo, S. Inglot (oprac.), Wydawnictwo Zakładu Narodowego im. Ossolińskich, Wrocław.

Górnicki Ł. (2003), Dzieje w Koronie Polskiej, H. Barycz (oprac.), Wydawnictwo Zakładu Narodowego im. Ossolińskich, Wrocław.

Herbordi Dialogus de vita s. Ottonis episcopi Babenbergensis (1974), J. Wikarjak, K. Liman (wyd.), [w:] Monumenta Poloniae Historica, Series Nova, t. viI.3, Państwowe Wydawnictwo Naukowe, Warszawa. 
Jagelló Zsigmond herceg udvarának számadáskönyve (I504-I507). The Court Account Book of Sigismund Jagiellon (I504-I507) (2014), K. Rábai, przy współpracy R.R. Trimonienė, P. Kaszy (wyd.), Quintus Kiadó, Szeged.

Joannis de Czarnkow Chronicon Polonorum (1872), J. Szlachtowski (wyd.), [w:] Monumenta Poloniae Historica, t. II, b.m.w., Lwów.

Kilka zabytków ustawodawstwa królewskiego i wojewodzińskiego w przedmiocie handlu i ustanawiania cen (1895), B. Ulanowski (wyd.), Wydawnictwo Komisyi Prawniczej Akademii Umiejętności w Krakowie, Kraków (Archiwum Komisyi Prawniczej, I).

Kodeks dyplomatyczny Śląska. Zbiór dokumentów i listów dotyczacych Śląsa, t. I, Obejmujący lata 97I-I204 (1956), K. Maleczyński (wyd.), Wrocławskie Towarzystwo Miłośników Historii, Wrocław.

Kodeks dyplomatyczny Wielkopolski, t. viII, Dokumenty z lat I4I6-I425 (1989), A. Gąsiorowski, T.Jasiński (wyd. i oprac.), A. Gąsiorowski (komentarzem opatrzył), Państwowe Wydawnictwo Naukowe, Warszawa-Poznań.

Ksiega przychodów i rozchodów miasta, t. I, I404-I4I4 (I896), A. Czołowski (wyd.), [w:] Pomniki dziejowe Lwowa $z$ archiwum miasta, t. II, Lwów.

Ksiega przychodów i rozchodów miasta, t. II, I4I4-I426 (1905), A. Czołowski (wyd.), [w:] Pomniki dziejowe Lwowa $z$ archiwum miasta, t. III, Lwów.

Ksiegi radzieckie kazimierskie I369-I38I i $1385-1402$ (1932), A. Chmiel (wyd.), Kraków.

Legenda śląska (1967), T. Wąsowicz (oprac.), Ossolineum, Wrocław-Warszawa-Kraków.

Matricularum Regni Poloniae summaria..., cz.3 (1908), T. Wierzbowski (wyd.), Warszawa.

Najstarsze księgi i rachunki miasta Krakowa od r. 1300 do I40o, cz.2 (I878), F. Piekosiński, J. Szujski (wyd.), Kraków.

Nowa ksiega rachunkowa Starego Miasta Elblaga I404-I4I4, CZ. 2, (I4II-I4I4) (1989), M. Pelech (wyd.), Państwowe Wydawnictwo Naukowe, Warszawa-Poznań-Toruń.

Podwody kazimierskie 1407-I432 (1909-1913), S. Krzyżanowski (wyd.), Wydawnictwa Komisyi Historycznej Akademii Umiejętności w Krakowie, Kraków (Archiwum Komisyi Historycznej, II).

Prawa, przywileje i statuta miasta Krakowa (I507-1795), t. I.I (I885), F. Piekosiński (wyd.), Nakładem Akademii Umiejętności Krakowskiej, Kraków.

Preussisches Urkundenbuch, t. I.I (I882), K.P. Woelky (wyd.), Königsberg.

Rachunki dworu króla Wtadystawa Jagietty i królowej Jadwigi z lat 1388 do 1420 (I896),

F. Piekosiński (wyd.), Nakładem Akademii Umiejętności, Kraków.

Rachunki królewskie z lat I47I-I472 i I476-I478 (1960), S. Gawęda, Z. Perzanowski, A. Strzelecka (wyd.), Wydawnictwo Zakładu Narodowego im. Ossolińskich, Wrocław-Kraków.

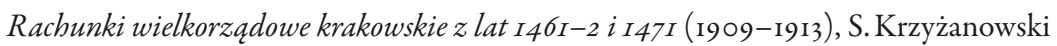
(wyd.), Akademia Umiejętności, Kraków (Archiwum Komisyi Historycznej, II).

Relacja Ibrāhima ibn Ja’kūba z podróży do krajów stowiańskich w przekazie Al-Bekrīego (1946), T. Kowalski przy współudziale J. Kostrzewskiego, K. Stołyhwy, K. Moszyńskiego, K. Nitscha (wyd.), [w:] Monumenta Poloniae Historica, Series Nova, t. I, Państwowe Wydawnictwo Naukowe, Kraków.

Sarnicki S. (2015), Ksieggi hetmańskie, M. Ferenc (oprac.), Towarzystwo Wydawnicze „Historia Jagellonica”, Kraków. 
Tarnowski J. (1987), Consilium rationis bellicae, T.M. Nowak (wyd.), J. Sikorski (wstęp), Warszawa.

Taryfa cen dla województwa krakowskiego z r. 1565 (I89I), F. Bostel (wyd.), Nakładem Akademii Umiejętności, Kraków (Archiwum Komisji Historycznej, 6).

Vita Sancti Uodalrici. Die älteste Lebensbeschreibung des heiligen Ulrich (1993), W. Berschin, A. Häse (wyd.), Carl Winter, Heidelberg.

\section{Opracowania}

Bołdyrew A. (2016), Equus Polonus. Koń w wojsku polskim w XVI wieku, Uniwersytet Jana Kochanowskiego. Filia, Piotrków Trybunalski.

Bołdyrew A. (2017), Sprzęt taborowy (wozy) w przemieszczeniu armii zaciężnej w Polsce za ostatnich Jagiellonów, „Acta Universitatis Lodziensis. Folia Historica”, 99 (= J. Kita, M. Pogońska-Pol (red.), Oblicza wojny. Wojsko w drodze), s. III-I24, https://doi.org/10.18778/0208-6050.99.06

Brzeska A. (2009), Inwentarz Zofii Jagiellonki jako źródto do poznania wyprawy ślubnej królewskiej córki, [w:] A. Januszek-Sieradzka (red.), Curia Jagiellonica. Studia z dziejów dworu i kultury dworskiej $w X V-X V I$ wieku, Wydawnictwo Diecezjalne i Drukarnia, Lublin, s. I2I-I49.

Buczek K. (1967), Publiczne postugi transportowe i komunikacyjne w Polsce średniowiecznej, „Kwartalnik Historii Kultury Materialnej”, 15.2, s. 255-268.

Bystroń J.S. (1994), Dzieje obyczajów w dawnej Polsce. Wiek XVI-XVIII, t. II, Państwowy Instytut Wydawniczy, Warszawa [Warszawa 1933: Wydawnictwo Trzaska, Evert i Michalski].

Cetwiński M., Derwich M. (1987), Herby, legendy, dawne mity, Krajowa Agencja Wydawnicza, Wrocław.

Dąbrowski J. (2007), Elżbieta Eokietkówna 1305-1380, Universitas, Kraków [Kraków 1914: Nakładem Akademii Umiejętności].

Dąbrowski K. (1975), Opactwo cystersów w Oliwie od XII do XVI wieku, Gdańskie Towarzystwo Naukowe. Wydział I Nauk Społecznych i Humanistycznych, Gdańsk (Seria Monografie, 53).

Dembińska M. (1978), Obstuga ruchu i sieć drożna, [w:] W. Hensel, J. Pazdur (red.), Historia kultury materialnej Polski w zarysie, t. I, M. Dembińska, Z. Podwińska (red.), Od VII do XII wieku, Zakład Narodowy Imienia Ossolińskich; Wydawnictwo Polskiej Akademii Nauk, Wrocław, s. 240-25I.

Dobroński A. (198I), Wóz, [w:] A. Mączak (red.), Encyklopedia historii gospodarczej Polski do I945 roku, [t. II], Wiedza Powszechna, Warszawa, s. 521-522.

Dyakowski B. (1911), Koń towarzysz cztowieka, Wydawnictwo M. Arcta, Warszawa.

Gloger Z. (1902), Encyklopedja staropolska ilustrowana, t. III, Warszawa.

Gloger Z. (1903), Encyklopedja staropolska ilustrowana, t. IV, Warszawa.

Górski K.(1902), Historya artyleryi polskiej, T. Korzon (wyd.), Skład główny w Księgarni E. Wende i S-ka, Warszawa.

Grabowski J. (1963), Uprząż i pojazd konny, Państwowe Wydawnictwo Rolnicze i Leśne, Warszawa. 
Jougan A. (1958), Stownik kościelny tacińsko-polski, wyd. III zmienione i uzupełnione, Księgarnia Św. Wojciecha, Poznań-Warszawa-Lublin.

Kołyszko M. (2007), Późnośredniowieczne zaprzegi z forytarzem w świetle źródet ikonograficznych, [w:] J. Olczak, A. Sosnowska (red.), Studia z dziejów wojskowości, budownictwa, kultury, Wydawnictwo Uniwersytetu Mikołaja Kopernika, Toruń (Archaeologia Historica Polona, 17), s. 19I-200.

Kopaliński W. (1991), Stownik symboli, wyd. 2, Wiedza Powszechna, Warszawa.

Kręt H. (1987), Dwór królewski Jadwigi i Jagietty, Polskie Towarzystwo Teologiczne, Kraków.

Kutyłowski R.(1974), Historia pojazdów kotowych, „Kwartalnik Historii Kultury Materialnej", 22.4, s. 728-734.

Kwiatkowski K. (2016), Wojska Zakonu Niemieckiego w Prusach I230-I525. Korporacja, jej pruskie wtadztwo, zbrojni, kultura wojny i aktywność militarna, przy współpracy M. Molendy, Wydawnictwo Naukowe Uniwersytetu Mikołaja Kopernika, Toruń.

Labuda G. (1999), Stowiańszczyzna starożytna i wczesnośredniowieczna. Antologia tekstów źródtowych, Poznańskie Towarzystwo Przyjaciół Nauk, Poznań.

Leciejewicz L. (1985), Za denara otrzymasz wóz świeżych śledzi..., [w:] S.K. Kuczyński, S. Suchodolski (red.), Nummus et historia. Pieniadz Europy średniowiecznej, PTAin, Warszawa, s. 103-109.

Linde M.S.B. (1858), Stownik jezzyka polskiego, t. IV, wyd. 3, Lwów [Warszawa 1959].

Marchwińska A. (2008), Królewskie dwory żon Zygmunta Augusta. Organizacja i sktady osobowe, Wydawnictwo Naukowe Uniwersytetu Mikołaja Kopernika, Toruń (Roczniki Towarzystwa Naukowego w Toruniu, 92.I).

Matuszewski J. (2002), Transport-przewóz w wiekach średnich, [w:] J. Matuszewski, Pisma wybrane, t. v, Wydawnictwo Uniwersytetu Łódzkiego, Łódź, s. 253-267, https://doi.org/10.18778/7171-516-1.0I

Mitkowski J. (1968), Kancelaria Kazimierza Konradowica księcia kujawsko-tęczyckiego (I233-I267), Zakład Narodowy im. Ossolińskich. Wydawnictwo Polskiej Akademii Nauk, Wrocław-Warszawa-Kraków.

Niesiołowska-Wędzka A. (1980), Wóz, [w:] G. Labuda, Z. Stieber (red.), Stownik starożytności stowiańskich. Encyklopedyczny zarys kultury Stowian od czasów najdawniejszych, t. vi.2, Zakład Narodowy im. Ossolińskich, Wrocław, s. 595.

Plewczyński M.(2005), Wojny Jagiellonów z wschodnimi i potudniowymi sasiadami Królestwa Polskiego w XV wieku, Wydawnictwo Akademii Podlaskiej, Siedlce (Monografie, 57).

Poklewski T.(1979), Dzieje Bolestawca nad Prosna, Federacja Towarzystw Kulturalnych Ziemi Kaliskiej, Kalisz.

Przezdziecki A. (I854), Życie domowe Jadwigi i Jagietty z regestrów skarbowych z lat 1388-1417, Skład główny w Księgarni Kommissowéj Z. Steblera, Warszawa.

Robak Z. (2009), Wczesnośredniowieczny wóz w Polsce, „Zborník Filozofickej fakulty Univerzity Komenského. Musaica”, 26, s. 175-188.

Russocki S. (1965), Powinność przewodu na tle postug transportowych Polski piastowskiej, „Kwartalnik Historii Kultury Materialnej”, 13.2, s. 243-268. 
Rutkowska G. (20I2), Podróże polskich królowych w xv wieku, [w:] M. Saczyńska, E. Wółkiewicz (red.), Samotrzeć, w kompanii czy z orszakiem? Spoteczne aspekty podróżowania w średniowieczu i wczasach nowożytnych, Instytut Archeologii i Etnologii Polskiej Akademii Nauk. Niemiecki Instytut Historyczny w Warszawie, Warszawa, s. 175-197.

Rutkowska-Płachcińska A. (1978), Urządzenia transportowe i komunikacyjne, [w:] W. Hensel, J. Pazdur (red.), Historia kultury materialnej Polski w zarysie, t. II, A. Rutkowska-Płachcińska (red.), Od XIII do XV wieku, Zakład Narodowy Imienia Ossolińskich. Wydawnictwo Polskiej Akademii Nauk, Wrocław, s. 204-223.

Samsonowicz A. (199I), Eowiectwo w Polsce Piastów i Jagiellonów, Zakład Narodowy im. Ossolińskich. Wydawnictwo Polskiej Akademii Nauk, Wrocław-Warszawa-Kraków (Studia i Materiały z Historii Kultury Materialnej, 62).

Stownik taciny średniowiecznej w Polsce, t. II.2 (1960), M. Plezia (red.), Zakład Narodowy im. Ossolińskich, Wrocław-Warszawa-Kraków.

Stownik polszczyzny XVI wieku, M.R. Mayenowa (red.), Zakład Narodowy im. Ossolińskich, t. II, Wrocław-Warszawa-Kraków 1967; t. III, Wrocław-Warszawa-Kraków 1968; t. X, Wrocław 1976; t. XXIV, Warszawa 1996.

Stownik staropolski, S. Urbańczyk (red.), Polska Akademii Umiejętności, Instytut Języka Polskiego PAN, t. I, Warszawa 1953-1955; t. III, Wrocław-Kraków-Warszawa 1960-1962; t. VI, Wrocław 1970-1973; t. VIII, Wrocław 1977-1981.

Sroka S.A. (1999), Elżbieta Eokietkówna, wyd. 2, Wydawnictwo Homini, Bydgoszcz.

Szymczak J. (2008), „Currus bellicalis”, czyli o wozach wojennych i ich wyposażeniu w średniowiecznej Polsce, [w:] Z. Pilarczyk, M. Franz (red.), Od najazdów pogańskich dotąd są państwa Waszej Królewskiej Mości spokojne.... Studia ofiarowane w siedemdziesiąta rocznice urodzin profesorowi Karolowi Olejnikowi, Wydawnictwo Adam Marszałek, Toruń, s. IO3-II6.

Szymczakowa A.(200I), Wyprawy szlachcianek sieradzkich w XV wieku, [w:] M. Malinowski (red.), Niebem i sercem okryta. Studia historyczne dedykowane dr Jolancie Malinowskiej, Wydawnictwo Adam Marszałek, Toruń, s. 139-I47.

Wółkiewicz E. (2012), ,Episcopus ambulans. Formy i organizacja podróży biskupów wroctawskich w późnym średniowieczu, [w:] M. Saczyńska, E. Wółkiewicz (red.), Samotrzeć, w kompanii czy z orszakiem? Spoteczne aspekty podróżowania w średniowieczu i wczasach nowożytnych, Instytut Archeologii i Etnologii Polskiej Akademii Nauk; Niemiecki Instytut Historyczny w Warszawie, Warszawa, s. 83-109.

Wrzesiński J.(2002), Środki i urządzenia komunikacyjne Polski wczesnopiastowskiej na podstawie dotychczasowych znalezisk archeologicznych, [w:] W. Dzieduszycki, M. Przybył (red.), Trakt cesarski. Ilawa Gniezno Magdeburg, Muzeum Archeologiczne w Poznaniu, Poznań (Bibliotheca Fontes Archaeologici Posnanienses, II), s. 217-246.

Zarys historii wtókiennictwa na ziemiach polskich do końca XVIII wieku (1966), J. Kamińska, I. Turnau (red.), Zakład Narodowy Imienia Ossolińskich. Wydawnictwo Polskiej Akademii Nauk, Wrocław-Warszawa-Kraków.

Żurawska T. (1982), Polskie powozy, Zakład Narodowy im. Ossolińskich, Wrocław. Żygulski Z.jun. (1999), 'Bitwa pod Orsza' - struktura obrazu, [w:] Światta Stambutu, Wydawnictwo DiG, Warszawa, s. 253-290. 


\title{
Summary
}

Vehicles were used to transport people, animals, goods and many other things, and therefore they have been accompanying man for a long time in his daily work, travel and war. According to the title of this article, its subject are very expensive vehicles for ladies and gentlemen, the great of this world, and less expensive, but with a solid structure for the little ones in medieval and early modern Poland. They were litters, cradles and carriages, but the roads were dominated by ordinary carts of merchants and peasants, used for traveling and transporting their belongings, goods and crops. The price of the car depended on its size, equipment and purpose. The cheapest cost 32 grossi ( $\mathrm{I}$ mark $=48$ grossi), but most often $2-3$ marks. The royal asseda dicta colebca in 1394 cost as much as 8 marks and it is the most expensive vehicle recorded in sources until the $\mathrm{I}^{\text {th }}$ century. The price list of Piotr Kmita, the voivode of Kraków from $\mathrm{I} 538$, lists 4 types of the most popular cars. The first is a chariot with a two-horse (currus alias Ridwan) for 2 florins ( $\mathrm{I}$ florin $=32$ grossi), the second is a medium chariot for 3.5 florins and the third great chariot for 5 florins. Similar prices are listed in the price lists from 156r and 1565. The bodies of uniaxial vehicles were made of boards or wicker in the shape of a short rectangle. In two-axle wagons they usually had the form of a more or less elongated rectangle and wooden, wicker or ladder sides. One of the most important and probably the most susceptible to deterioration and destruction in every car were its wheels. Depending on the purpose and weight of the transported items, they cost from 6 to 24 grossi. Vehicles or their parts were often covered with canvas or cloth tarpaulins, such as poklat, tectura, patuba, popona, coopertio, hung on wooden or iron arches. Such covered wagons cost up to Io marks, but were at their disposal by rulers and wealthy people.

Keywords: Poland, $\mathrm{IO}^{\text {th }}-16^{\text {th }}$ century, vehicles, their names, construction, prices

\author{
Alicja Szymczak \\ Uniwersytet Łódzki \\ Wydział Filozoficzno-Historyczny \\ Instytut Historii \\ e-mail: alicja.szymczak@uni.lodz.pl
}

\author{
Jan Szymczak \\ Uniwersytet Łódzki \\ Wydział Filozoficzno-Historyczny \\ Instytut Historii \\ e-mail: jan.szymczak@uni.lodz.pl
}

(c) by the author, licensee University of Lodz - Lodz University Press, Łódź, Poland. This article is an open access article distributed under the terms and conditions of the Creative Commons Attribution license CC-BY-NC-ND 4.0 (https://creativecommons.org/licenses/by-nc-nd/4.0/) 